\title{
Regulation of Acquisitions Activity in Banking Industry - Albanian Banking System
}

\author{
Phd. Av. Ergys Misha \\ Lawyer \\ Email: ergys_2005@yahoo.it
}

\section{Doi:10.5901/mjss.2015.v6n1p325}

\section{Abstract}

Throughout the world, banking industries are undergoing a rapid and sometimes startling process of consolidation, spurred occasionally by hostile takeover bids, but, more often, by friendly mergers by institutions that were once fierce competitors. Many changes have happened also to the Albanian banking sector those last years. Well known European banks have been taking an increased interest in Albania which has been finalized with a growing number of takeovers of local banks/financial institutions by western banks. The primary objective of the Supervisory Authority - Bank of Albania, therefore, should be to ensure that a merger will not be detrimental to the public interest and also not contrary to the interests of the banks concerned, their depositors or their controlling companies. Also the government intervention is necessary to restrain the behavior of bank management and to ensure the soundness of the financial system because of the negative impact of bank failures on economic activity. This paper analyzes the Albanian regulatory framework regarding acquisition process, and the compliance with particular core principle for effective banking supervision. Also, it describes the main regulatory principles that the regulators should take into account when considering particular applications.

Keywords: Regulation, Acquisitions, Banking Industry, Contagion Risk, Albanian Banking Law, Bank of Albania.

\section{Introduction / Methodology}

This paper is a descriptive analysis of the banking system, macro view. The data used are from the banking system and the regulatory agencies, mainly the Bank of Albania, addition to Basel Core Principles for effective banking supervision. The data include manuals and regulations of the Bank of Albania for banking supervision. This is more a "case study" for Albania banking sector, based specifically on banking legislation. The paper gives a description of the facts, based on behavior, records, financial indicators, etc., on the performance of the banking system in Albania, and trends for the future.

\section{Trends and Reasons for Bank Acquisitions in Albania}

Many changes have happened to the Albanian banking sector. Well known European banks have been taking an increased interest in Albania. One of the largest Italian banks, San Paoli IMI, has bought a majority stake in the American Bank of Albania, having bought great part of the BIA (Italian-Albanian Bank) before. Austria's Raiffeisen Bank has bought the state-owned Savings Bank of Albania, the biggest bank in the system. Other takeovers include ex Dardania Bank, bought by an Italian bank and renamed as BIS Banca and the last one, Societe Generale took over $75 \%$ of Popular Bank, a young Albanian bank owned by a number of Albanian businessmen. Moreover the Emporiki bank in Greece, which operates also in Albania, was taken over by Credit Agricole.

This interest towards Albania and other Eastern European emerging markets, has finalized with a growing number of takeovers of local banks/financial institutions by western banks. It's a growing trend, last fall 3 of the 7 Albanian insurance companies were acquired by foreign firms, 2 Austrian companies (one is Uniqa) and one from Cyprus. Another fourth company is in negotiation process with an insurance company from Israel.

But why this trend? It can be explained by some reasons:

1. Attractive growing market, the banking system and the insurance market are sound and safe, and yet unexploited. Banks and insurance companies had good performance and have strengthened their financial stability

2. It is easier for a foreign company/bank to enter the market in this way, by taking over or merging with a local bank. This is because of:

a. Less time needed to enter the market than by applying for a license 
b. Lower costs of entering the market

c. Having already an installed bank structure, a market share and good portfolio

d. Good expertise in the local market

3. Bank products and services are still poor in Albanian market, especially in retail banking, internet banking, and especially investment products. There is no investment banking actually in the country.

4. The country is in an European integration process, which means reforms and efforts are made to orient the economy towards EU parameters. The financial sector is probably the most advanced in this point. Inflation has been under control for the last 9 years, the local currency is stable and banks are accurately controlled by the Central Bank (Bank of Albania).

\section{Regulatory Concerns with Regard to Acquisition}

The ultimate objectives of a financial services institution whether it is a bank, insurance company or securities firm, are, firstly, to be financially safe and sound; secondly, to obtain the confidence of and show fairness to the users of its financial services; and, finally, to be efficient and effective. These objectives should always be consistent with the objectives of the regulatory authorities.

The objectives of the regulator are:

- Ensure a safe, sound and stable financial system.

- Enhance the confidence of and fairness to investors, by eliminating bad business practices and ensuring healthy competition between financial institutions.

- Ensure an efficient and effective financial system.

It follows that the strategies adopted by banks as financial services institutions and the objectives set by the regulator have to be consistent with each other. The priorities assigned to the ultimate objectives of a bank may, however, differ from those of the regulator. For instance, the bank may have as its primary ultimate objective the maximization of shareholder value, as measured by the rate of return on equity. This would be in conflict, however, with regulatory objectives if maximization of shareholder value were to be achieved by the taking of excessive risks.

The primary objective of the Supervisory Authority - Bank of Albania, therefore, should be to ensure that a merger will not be detrimental to the public interest and also not contrary to the interests of the banks concerned, their depositors or their controlling companies.

We must remember that the responsibility of the directors is to act in the best interest of their shareholders and, thereby, improve or maintain the wealth of their shareholders. The interest of the public and depositors is thus not the primary concern or responsibility of the directors. It is, therefore, imperative that Supervisory Authority protects the interest of depositors.

Our task, as regulators, is to ensure that, after a merger, acquisition, reconstruction or takeover, a bank or banking group has:

- Suitable shareholders;

- Adequate financial strength;

- A legal structure that is in line with the bank or banking group's operational structure;

- Management with sufficient expertise and integrity.

We are sensitive to the fact that it is not the role of the Bank Supervision Department to judge the wisdom of management decisions and business strategies beyond ensuring that local and international best practice regarding supervision and regulation are met. Our philosophy is that market principles underlie all activities.

The following are regulatory concerns, because they could impact on the stability of the financial system as a whole:

\subsection{Contagion risk}

In the case of a bank, contagion can best be described as the risk that a problem or problems in one or more associate entities contaminate the bank, leading to negative perceptions of the bank. In some cases, the implications could be so serious as to lead to the failure of the bank. As the potential for contagion increases, so, too, increases the risk of individual financial failure. Although contagion risk is extremely difficult to measure and quantify, it is a risk of which bank management constantly needs to be aware.

Banks operate in a highly competitive environment, encouraged by the developments of new markets, instruments 
and techniques. Although many of these changes provide the means of diversifying risks, they also allow greater risks to be taken. These developments provide challenges to central banks in attaining the appropriate balance between risk and stability in the financial system. It is the central bank's responsibility to provide a financial system in which the users of financial services can benefit from healthy competition between financial institutions, but, at the same time, to ensure public confidence in the monetary system as a whole.

\subsection{Systemic risk}

Systemic risk is the possibility that the failure of one bank to settle net transactions with other banks will trigger a chain reaction, depriving other banks of funds and, in turn, preventing them from closing their positions. The consequence is frequently loss of confidence in the whole banking system.

\section{3 "Lender-of-last-resort" assistance}

One of the main responsibilities of a central bank is to prevent financial system instabilities. When pressures that cannot be avoided by preventive supervision do arise, central banks should try to contain these pressures through direct central bank intervention, acting as "lender of last resort". This should never be seen as an automatic facility available to all banks in distress, but should be used only when the failure of a bank would pose a serious threat to the financial system as a whole. The primary aim of the "lender of last resort" facility is therefore not to save the bank in distress, but rather to consider the effect that the failure might have on the system and what should be done to protect the system from contagion.

\section{4 "Too big to fail" factor}

What do we mean when we say a financial institution is too big to fail? This term might best be applied to an institution that is so large that its activities make up a significant portion of a country's payment system, credit-granting process, or other key financial roles. As a result, any substantial disruption in the particular institution's operations would be likely to have a serious effect on a country's financial markets, either preventing the markets from operating properly or raising questions about their integrity. The consequence of the "too big to fail" factor is that countries extend protection to large institutions and their customers that is not granted to others.

\section{Albanian Regulatory Framework and Basel Core Principles}

\subsection{Albanian Banking Law}

In June 1, 2007, the new Banking Law for the banks operating in the Republic of Albania, entered into force. The sections of the Banking Law that are related to acquisitions are the following:

\subsubsection{Article 24 - Preliminary Approvals}

In essence, this Article provides that prior permission must be obtained from the Bank of Albania if a shareholder wishes to increase its shareholding beyond 20,33 or 50 percent of the capital or of the voting rights of a bank. Permission for the acquisition of shares in a bank is not given lightly and is granted only if the Bank of Albania is satisfied that the proposed acquisition of shares is not contrary to the public interest and is also not contrary to the interest of the bank concerned or its depositors.

\subsubsection{Article 12 - The Shares of a Bank}

According to our law, the shares of a bank may only be of the nominative type and they should be fully paid-up in money. The objective is to identify the true power behind the bank, because of the potential for the misuse of depositor funds by unscrupulous owners. 


\subsubsection{Article 70 - Investments in Capital}

In terms of Article 70 of Banking Law, the bank cannot invest more than 15 percent of its regulatory capital in shares of undertakings other than banks or financial institutions. The aggregate amount of a bank investments in these undertakings may not exceed 60 percent of its regulatory capital.

\subsection{Core Principles for Effective Banking Supervision}

The Core Principles for Effective Banking Supervision were originally issued by the Basel Committee on Banking Supervision in 1997. These Principles have been used by countries as a benchmark for assessing the quality of their supervisory systems and for identifying future work to be done to achieve a baseline level of sound supervisory practices. The particular principles that have a bearing on reconstructions, mergers and acquisitions are the following:

\subsection{Principle 7 - Major acquisitions or investments by a bank}

"The supervisor has the power to approve or reject (or recommend to the responsible authority the approval or rejection of), and impose prudential conditions on, major acquisitions or investments by a bank, against prescribed criteria, including the establishment of cross-border operations, and to determine that corporate affiliations or structures do not expose the bank to undue risks or hinder effective supervision".

From a supervisory perspective, we need to determine whether the banking organization has both the financial and the managerial resources to fund the acquisition. We may also need to consider whether the investment is permissible under existing banking legislation. The Bank of Albania shall refuse the request for issuing the approval for the acquisition of a qualifying holding, if the information available to it indicates that:

1. The qualification, experience and reputation of the new shareholders are not suitable for banking and financial operations plan and could affect negatively the bank's risk management;

2. The activities or operations performed by the qualified owners could hinder or make substantially more difficult the supervision of the bank ;

3. It would result in a large concentration in the banking system that might limit the freedom of market competition;

4. It could adversely influence the implementation of monetary policy and foreign exchange regime in the Republic of Albania.

The Banking Law, by its nature, allows taking a wide array of risks. We, as supervisors, need to understand these risks and need to be satisfied that banks are adequately measuring and managing the risks.

\subsubsection{Principle 12 - Consolidated supervision}

"An essential element of banking supervision is that supervisors supervise the banking group on a consolidated basis, adequately monitoring and, as appropriate, applying prudential norms to all aspects of the business conducted by the group worldwide".

Bank of Albania conducts the supervision of banking and financial groups on the basis of consolidated financial statements and supervisory reports. This includes the ability to review both the banking and the non-banking activities conducted by the banking organization, either directly or indirectly (through subsidiaries and affiliates), and activities conducted at both domestic and foreign offices. In this regard, it is important that we, as supervisors, take into account that the non-financial activities of a bank or group may pose risks to the bank.

A banking group must define the consolidated position of:

- Regulatory Capital

- Capital adequacy Ratio

- Risk Exposures

- Net Open Positions

- Investments in the capital of non-financial institutions 


\subsubsection{Principle 13-Home-host relationships:}

"Home and host supervisors of cross-border banking groups share information and cooperate for effective supervision of the group and group entities, and effective handling of crisis situations. Supervisors require the local operations of foreign banks to be conducted to the same standards as those required of domestic banks"

Information to be exchanged by home and host supervisors should be adequate for their respective roles and responsibilities. Bank of Albania reaches agreements with other competent supervisory authorities in Albania or in other states responsible for the supervision of an individual subordinate bank in a banking group to share the tasks related with the operations' supervision for the banking group. A minimum level of information on the bank or banking group will be needed in most circumstances, but the overall frequency and scope of this information will vary depending on the materiality of a bank's or banking group's activities to the financial sector of the host country. From the host supervisor perspective, home and host supervisors of a banking group share their supervisory stands or supervisory concerns in the meetings of college of supervisors. In addition the communication between home and host supervisor may take place in formal or informal ways on certain issues.

A host supervisor's national laws or regulations require that the cross-border operations of foreign banks are subject to prudential, inspection and regulatory reporting requirements similar to those for domestic banks. Banking law and regulations do not distinguish and treat equally all the domestic or foreign banks (or branches of foreign banks) that operate in Albania. All the requirements of law or regulations are applicable to all banks and branches of foreign banks.

\section{Regulatory Principles}

The considerations that are taken into account when considering applications are the following:

\subsection{Management structure}

It is a known fact that by far the most common underlying cause for bank failure is bad management.

We cannot involve ourselves in the day-to-day operational decisions or, even, strategies of a bank, since to do so would not only impair our objectivity in assessing the health of a bank, but would be too costly and probably too restrictive. It follows that we have to rely heavily on the competence and integrity of management. Therefore, the following aspects are of importance:

\subsubsection{Ability and integrity}

Banks and banking groups should be managed only by directors and management with a proved ability and integrity to pursue the interests of shareholders without harming the interests of depositors.

Management should at all times put the interests of the organization and depositors before their own and should act in the best interest of depositors. It is important that the management of a merged entity has the ability to identify the risks and to bed down the merger in the shortest possible time.

\subsubsection{Experience and skills}

The proposed management and directors should have the relevant banking experience and skills to conduct the proposed business.

\subsection{Corporate governance, audit and internal control}

Aspects relating to corporate governance, audit and internal control that are important include the following:

\subsubsection{Corporate governance}

After a merger or takeover, a banking group has to demonstrate its ability to maintain appropriate corporate governance, management, internal control and risk-management systems, including internal audit and a compliance officer, in order to monitor and limit all the risk exposures of a banking group as of the commencement of business. 


\subsubsection{Audit and internal control}

Since management cannot be everywhere, management has to rely on systems of internal control to ensure the smooth operation of a bank.

\subsection{Capital}

Several aspects relating to capital are relevant:

\subsection{Importance of capital}

Ensuring adequate levels of capital promotes public confidence in the particular banking group and the entire banking system. A merged entity should have adequate capital to meet both regulatory requirements and its own internal requirements, taking into account its risk profile.

\subsection{Purposes of capital}

Capital serves the following four purposes:

- It provides a permanent source of revenue for the shareholders and funding for the bank.

- It is available to bear risk and to absorb losses.

- It provides a base for further growth.

- It gives the shareholders reason to ensure that the bank is managed in a safe and sound manner.

\subsubsection{Capital adequacy}

Minimum capital-adequacy ratios are necessary to reduce the risk of loss to depositors, creditors and other stakeholders of a bank and to help us to pursue the overall stability of the banking system.

This ratio is 12 percent according to Albanian Regulatory Framework. In a merger or acquisition, any current or consequential cross-shareholding should also be eradicated in order to avoid double counting of capital.

\subsubsection{Availability of additional capital}

We also have to assess the ability of the major shareholders of a merged entity to provide additional capital should the bank or banking group experience financial difficulties.

\subsection{Risk concentration}

Concentrations of risks cannot be eliminated; concentrations will arise through the specialization of banks for reasons of competitive advantage and expertise. The risk can and must, however, be contained by ensuring that the exposure of a bank or a banking group is diversified.

Banks should manage their credit risk prudently to ensure that there are no undue concentrations of risks to individual entities, associates, industries geographical areas, sectors or banking products. The risks of a merged entity should not be more than the risks of the two stand-alone entities.

\subsection{Risk-management profile}

The emphasis on risk management is most critical at our largest, most sophisticated banks and most internationally active banks. Many of these banks use advanced economic and statistical models to evaluate their market and credit risks. These models are used for a variety of purposes, including allocating capital on a risk-adjusted basis and pricing loans and credit guarantees.

\subsection{Information technology system integration}

Information technology systems should be able to provide management information that is accurate, timeous and relevant 
to manage the bank's risks. A bank's system should be integrated, there should be minimal manual intervention, and the risks emanating within various departments or divisions should be consolidated in the management reports.

Implementation of information technology systems is one of the biggest risks for a merged entity, and may have substantial negative impact on all stakeholders if all does not go well.

\section{Recent Developments Leading Banks to Acquisition}

Throughout the world, banking industries are undergoing a rapid and sometimes startling process of consolidation, spurred occasionally by hostile takeover bids, but, more often, by friendly mergers by institutions that were once fierce competitors. Several reasons that drive banks to merge can be identified:

Firstly, banks are tussling with the same technology, delivery and customer-service issues that have become pressing for major international banks. Banks are feeling forces of globalization and technological change and must invest huge amounts in their own information technology systems. The electronic revolution also undermines the traditional role of banks as intermediaries between borrowers and savers, in the process reducing banks' profits. This, in turn, is forcing banks to cut costs more urgently, and a merger with another bank becomes an attractive option for a bank.

Advances in information technology also open up a growing array of delivery channels. Online banking, in all its increasingly varied forms, is poised to become a key channel for transacting banking business. The importance of physical branches in a cyber-world may decline and the nature of the services that branches provide will probably change. Technology is here to stay, and the challenge is for bankers to embrace technology to their own and their customers' advantage.

Secondly, in Europe, economic, monetary and financial unity has implied increased competition among banks and is forcing them to seek ways to cut costs and to increase market share.

Thirdly, it is believed that the banking and securities industry might in time consolidate into about 15 world megafirms and that the financial institutions that do not merge soon, increase their size and obtain market share might be left in the cold.

Fourthly, it is believed that banks might become too small to compete effectively, except in niches, either in terms of products or geographically. In several countries, governments and regulators are urging banks to merge not because the merger would make them better, safer or more profitable, but because it would allow them to compete internationally with the main American and European banks.

What governments and regulators should keep in mind is that, very often, the best way to create local banks that can compete internationally is to allow international banks to compete locally.

Fifthly, the choicest merger partners are taken up very rapidly. It is believed that if a bank does not act soon, it might be left with an unattractive merger partner.

\section{Disadvantages of Bank Acquisition}

As long as barriers keep out international competitors, mergers may reduce competition and may hurt consumers.

Bigger banks are not necessarily safer than smaller ones. In a report published by the Bank for International Settlements, it is stated the current restructuring of the banking industry could cause constraints as competitive pressures interact with stubborn cost structures and heightened incentives for risk taking. This trend is especially dangerous since bigger banks are more likely considered to be "too big to fail".

The international movement towards the consolidation of banking systems has held promise for more efficient, better diversified banks, with more intense competition in local markets. In many cases, especially when acquirers paid a reasonable price and manage the resulting post-merger organizational problems effectively, this promise has certainly come true.

There is, however, accumulating evidence in surveys and empirical research that the promise has not always been fulfilled for retail customers in local banking markets. In many cases, neither greater efficiency nor substantial improvements in diversification appear to have been realized.

The Bank for International Settlements found, and several large banks are learning, that the alleged benefits of banks merging for reasons of profitability often prove to be illusionary.

\section{Lessons Learned from Acquisition}

Despite the continued pace of acquisition activity, new deals are meeting with increasing skepticism among investors. 
The reason is simple - most acquirers have simply not delivered the benefits that were promised. A study by the US Federal Reserve concluded that 50 percent of mergers by big banks in the United States of America eroded returns, whereas only 17 percent produced positive returns.

Although it is not our role to judge the appropriateness of any particular deal, a number of initial lessons may be drawn, so it would be better to make three comments in this respect:

\subsection{Improvement in profitability is not an automatic consequence of a merger}

Some recent work has shown that the improvement in profitability has not necessarily been related to size and that the definition of optimal size varies according to the type of institution, activity and business conducted.

Beyond this observation, the restructuring can come up against significant obstacles. For example, the compatibility of respective information systems might cause specific difficulties, the handling of which may turn out to be delicate. The increasing number of decision-making centers and structural differences may affect the efficiency of internal control systems. Some deals have revealed problems relating to the integration of different corporate cultures.

\subsection{To be effective these deals need to be part of strategic plans}

Another lesson from the American and European experience is that, from now on, credit institutions can no longer contemplate their future without carefully thinking about the changes in their economic, legal and financial environment.

Mergers and acquisitions will be successful when they are part of a strategy aimed at striking a balance between the need to strengthen existing product lines (when the comparative advantage is in principle at its greatest) and the diversification of activity, as part of medium-term plans aiming at extensively reorganizing both distribution channels and means of production.

\subsection{The emergence of trans-national banking groups will bring new risks, requiring closer cooperation between national banking supervisors}

Banking supervisors are responsible for accompanying the restructuring in order to preserve and reinforce the integrity of the banking system as a whole, notably as regards, in particular, interbank operations and payment systems. Banking supervisors must be vigilant to avoid any particular project bringing additional risks. Risks can increase significantly should larger banks be tempted to conquer new markets. The risk of contagion may grow correspondingly, weakening the banking system as a whole. It is therefore imperative that banking supervisors remain vigilant with regard to increasingly complex operations.

\section{Conclusions}

The reconstruction of a banking group, or mergers within a banking group, or the acquisition of subsidiaries, joint ventures and branch offices by banks or their controlling companies should be in the interest of stability of the banking system as a whole. It must, however, be stressed that there are no hard and fast rules, because special circumstances, such as the history of a group and certain practicalities, often necessitate a pragmatic approach.

As mentioned earlier, it is not our role, as regulators, to judge the wisdom of management decisions and business strategies beyond ensuring that local and international best practice regarding supervision and regulation are met.

The restructuring of the banking industry represents a challenge for bankers and for regulators.

Besides the strengthening of supervisory arrangements, it is up to the regulators to support the wave of restructuring by continuing to level the playing-field in the banking industry and by eliminating any competitive distortions. This condition needs to be met for restructuring to have its full effects in terms of economic efficiency and proper resource allocation.

\section{References}

Banking Law in the Republic of Albania, No. 9662, date 08.02.2006.

Basel Core Principles. The revised Core Principles were endorsed by banking supervisors at the 17th International Conference of Banking Supervisors held in Istanbul, Turkey, on 13-14 September 2012.

Inspection Manual of Banking Supervision, Bank of Albania, year 1999, reviewed. 
Speech of Governor Ardian Fullani, in Bank of Albania Conference "Financial Stability", Sept. 2009

Regulation "On the core management principles of banks and branches of foreign banks and the criteria on the approval of their administrators", No. 63, date 25.12.2012, Bank of Albania.

Enhancing Corporate Governance, BIS Paper.

The final version of this paper has been published in October 2010. http://www.bis.org/publ/bcbs176.htm

"Monitor" Magazine, 2011 